\title{
Fermentative hydrogen production from agroindustrial lignocellulosic substrates
}

\author{
Valeria Reginatto $^{1}$, Regina Vasconcellos Antônio ${ }^{2}$ \\ ${ }^{1}$ Departamento de Química, Faculdade de Filosofia, Ciências e Letras de Ribeirão Preto, \\ Universidade de São Paulo, Ribeirão Preto, SP, Brazil. \\ ${ }^{2}$ Universidade Federal de Santa Catarina, Araranguá, SC, Brazil.
}

Submitted: February 5, 2014; Approved: October 9, 2014.

\begin{abstract}
To achieve economically competitive biological hydrogen production, it is crucial to consider inexpensive materials such as lignocellulosic substrate residues derived from agroindustrial activities. It is possible to use (1) lignocellulosic materials without any type of pretreatment, (2) lignocellulosic materials after a pretreatment step, and (3) lignocellulosic materials hydrolysates originating from a pretreatment step followed by enzymatic hydrolysis. According to the current literature data on fermentative $\mathrm{H}_{2}$ production presented in this review, thermophilic conditions produce $\mathrm{H}_{2}$ in yields approximately $75 \%$ higher than those obtained in mesophilic conditions using untreated lignocellulosic substrates. The average $\mathrm{H}_{2}$ production from pretreated material is $3.17 \pm 1.79 \mathrm{mmol}$ of $\mathrm{H}_{2} / \mathrm{g}$ of substrate, which is approximately $50 \%$ higher compared with the average yield achieved using untreated materials $\left(2.17 \pm 1.84 \mathrm{mmol}\right.$ of $\mathrm{H}_{2} / \mathrm{g}$ of substrate). Biological pretreatment affords the highest average yield $4.54 \pm 1.78 \mathrm{mmol}$ of $\mathrm{H}_{2} / \mathrm{g}$ of substrate compared with the acid and basic pretreatment -

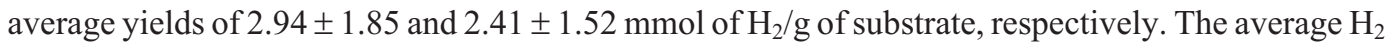
yield from hydrolysates, obtained from a pretreatment step and enzymatic hydrolysis $(3.78 \pm$ $1.92 \mathrm{mmol}$ of $\mathrm{H}_{2} / \mathrm{g}$ ), was lower compared with the yield of substrates pretreated by biological methods only, demonstrating that it is important to avoid the formation of inhibitors generated by chemical pretreatments. Based on this review, exploring other microorganisms and optimizing the pretreatment and hydrolysis conditions can make the use of lignocellulosic substrates a sustainable way to produce $\mathrm{H}_{2}$.
\end{abstract}

Key words: fermentation, hydrogen, lignocellulosic substrates, pretreatment, inhibitors.

\section{Introduction}

$\mathrm{H}_{2}$ is a promising fuel: it is carbon-free and its combustion produces only water (Wang and Wan, 2009). Although $\mathrm{H}_{2}$ constitutes a clean fuel, currently available methods leading to its production, such as methane reforming and partial oil and coal oxidation, demand fossil fuels and a high amount of energy (Chaubey et al., 2013). Biological approaches that produce $\mathrm{H}_{2}$ offer several advantages over current physicochemical methods: they occur at ambient temperature and pressure, and they use renewable raw materials as substrates ( $\mathrm{Li}$ and Fang, 2007; Li et al., 2012).
A number of microbes belonging to a wide variety of bacterial groups can perform fermentative $\mathrm{H}_{2}$ production, also called dark fermentation because it does not require light. The strict anaerobe Clostridium spp. and facultative anaerobes from the family Enterobacteriaceae are the most often cited $\mathrm{H}_{2}$-producing bacteria (Seol et al., 2008, Elsharnouby et al., 2013).

Mixed cultures that usually originate from an anaerobic environment, such as the sludge from anaerobic biodigestors, have also found application in $\mathrm{H}_{2}$-producing processes. They resist the fluctuations typical of the fermentation process, consume a broader range of complex substrates, and can operate in a non-sterile environment

Send correspondence to V. Reginatto. Departamento de Química, Faculdade de Filosofia, Ciências e Letras de Ribeirão Preto, Universidade de São Paulo, 14040-901 Ribeirão Preto-SP, Brazil. E-mail: valeriars@ffclrp.usp.br. 
(Valdez-Vazquez and Poggi-Varaldo, 2009, Kothari et al., 2012, Show et al., 2012; Rafrafi et al., 2013).

However, it is the choice of substrate for fermentative $\mathrm{H}_{2}$ production that determines the feasibility of the process. The substrate should (1) be carbohydrate-rich, (2) originate from renewable resources, (3) suffice for fermentation, and (4) promote energetically favorable energy recovery. In addition, any necessary pretreatment should be inexpensive (Wang and Wan, 2009; Chaubey et al., 2013). In this context, several investigators have turned to lignocellulosic materials to produce $\mathrm{H}_{2}$ (Kapdan and Kargi, 2006; Ren et al., 2009; Lin et al., 2012). According to Kotay and Das (2008), if the use of these resources is appropriately controlled, they will become a major source of energy in the future. Unfortunately, these residues have a complex chemical structure and often call for previous treatment and/or hydrolysis to serve as substrate for biological $\mathrm{H}_{2}$ production. Such pretreatment and/or hydrolysis could not only alter the physicochemical features of the waste, making carbohydrates available for fermentation, but also afford byproducts that negatively interfere in fermentative $\mathrm{H}_{2}$ production.

This review compares the yields of fermentative $\mathrm{H}_{2}$ production from (1) different agroindustrial lignocellulosic substrates without any chemical or biological pretreatment (2) lignocellulosic materials after a pretreatment step and (3) hydrolysates of lignocellulosic materials originating from a pretreatment step followed by enzymatic hydrolysis. The comparison of these results will show how the pretreatment and hydrolysis of lignocellulosic substrates affect fermentative $\mathrm{H}_{2}$ production. In addition, this review will present the microorganisms involved in $\mathrm{H}_{2}$ production from those materials.

\section{Lignocellulosic Materials as Substrate for Fermentative $\mathrm{H}_{2}$ Production}

Lignocellulosic materials are the most abundant residues derived from agroindustrial activities; therefore, they can potentially become a significant source of renewable $\mathrm{H}_{2}$ (Saratale et al., 2008; Levin et al., 2009; Ren et al., 2009; Cheng et al., 2011; Hay et al., 2013). Agricultural residues from harvested crops are the cheapest and the most abundant readily available lignocellulosic organic waste; they include straw, stover, peelings, cobs, stalks, and bagasse (Guo et al., 2010a; Cheng et al., 2011; Li et al., 2012). All these residues can undergo biological transformations to varying degrees, as well as conversion to hydrogen (Guo et al., 2010a).

Researchers have investigated several agroindustrial wastes for $\mathrm{H}_{2}$ production. Cornstalk (Cao et al., 2009; Cao et al., 2012; Cheng et al., 2012; Song et al., 2012; Zhao et al., 2013), wheat straw (Fan et al., 2006; Kaparaju et al., 2009; Kongjan and Angelidaki, 2010; Nasirian et al., 2011, Quemeneur et al., 2012a) and sugarcane bagasse (Pattra et al., 2008; Chairattanamanokorn et al., 2009; Fangkum and Reungsang, 2011) are the most cited in the literature.

Lignocellulosic materials consist primarily of cellulose, hemicelluloses, and lignin. Thus, the main products of the enzymatic, chemical, or thermochemical hydrolysis of lignocellulosic materials are hexoses, mainly glucose, and pentose sugars, mainly xylose.

In addition to $\mathrm{H}_{2}$, the anaerobic digestion of glucose by strict anaerobes or facultative microorganisms yields different final products. Depending on the bacterial species, $\mathrm{pH}$, and $\mathrm{H}_{2}$ partial pressure, the fermentation of glucose can result in $\mathrm{H}_{2}, \mathrm{CO}_{2}$, acetate and/or butyrate (Eqs. 1 and 2). Theoretically, when the final product is acetate only, $4 \mathrm{~mol}$ of $\mathrm{H}_{2} / \mathrm{mol}$ of glucose can emerge (Eq. 1). However, if the final product is butyrate, only $2 \mathrm{~mol}$ of $\mathrm{H}_{2} / \mathrm{mol}$ of glucose arises (Eq. 2).

Xylose is the major pentose derived from the hydrolysis of hemicelluloses, which in turn constitutes approximately 20 to $30 \%$ of plant biomass. It can be used for the growth and energy production of numerous microorganisms. The use of xylose as a substrate for ethanol production has been extensively studied (Sun and Cheng, 2002; Lin and Tanaka 2006; Sarks et al., 2014). However, only recently has attention been given to $\mathrm{H}_{2}$ production from xylose fermentation. Theoretically, similarly to glucose fermentation, xylose fermentation can produce $3.33 \mathrm{~mol}$ $\mathrm{H}_{2} /$ mol xylose when acetate is the fermentation product (Eq. 3). When butyrate is the fermentation product, $1.66 \mathrm{~mol}$ of $\mathrm{H}_{2} / \mathrm{mol}$ of xylose will emerge (Eq. 4) (Martin del Campo et al., 2013).

$$
\begin{aligned}
& \mathrm{C}_{6} \mathrm{H}_{12} \mathrm{O}_{6}+2 \mathrm{H}_{2} \mathrm{O} \rightarrow 2 \mathrm{CH}_{3} \mathrm{COO}^{-}+2 \mathrm{CO}_{2}+4 \mathrm{H}_{2} \\
& \mathrm{C}_{6} \mathrm{H}_{12} \mathrm{O}_{6} \rightarrow \mathrm{CH}_{3} \mathrm{CH}_{2} \mathrm{CH}_{2} \mathrm{COO}^{-}+2 \mathrm{CO}_{2}+2 \mathrm{H}_{2} \\
& \mathrm{C}_{5} \mathrm{H}_{10} \mathrm{O}_{5}+1.66 \mathrm{H}_{2} \mathrm{O} \rightarrow \\
& 1.66 \mathrm{CH}_{3} \mathrm{COO}^{-}+1.66 \mathrm{CO}_{2}+3.33 \mathrm{H}_{2} \\
& \mathrm{C}_{5} \mathrm{H}_{10} \mathrm{O}_{5}+1.66 \mathrm{H}_{2} \mathrm{O} \rightarrow \\
& 1.66 \mathrm{CH}_{3} \mathrm{CH}_{2} \mathrm{CH}_{2} \mathrm{COO}^{-}+1.66 \mathrm{CO}_{2}+1.66 \mathrm{H}_{2}
\end{aligned}
$$

Figure 1 shows the main steps of the metabolic pathways and enzymes leading to $\mathrm{H}_{2}$ production throughout glucose and xylose fermentation performed by anaerobic microorganisms. The figure shows that the enzyme xylose isomerase (XI) catalyzes the isomerization of xylose to xylulose. The latter is then phosphorylated by xylulokinase (XK), to afford xylulose-5-phosphate, one of the intermediates of the pentose phosphate (PP) pathway. Through the activities of epimerase, isomerase, transketolases, and transaldolases, enzymes of the PP pathway, xylulose-5phosphate is converted to fructose-6-phosphate and glyceraldehyde-3-phosphate. Both of these compounds are intermediates of the EMP pathway, through which they undergo conversion to pyruvate. The supposed activities of pyruvate, ferredoxin oxyreductase (PFOR) and ferredo- 


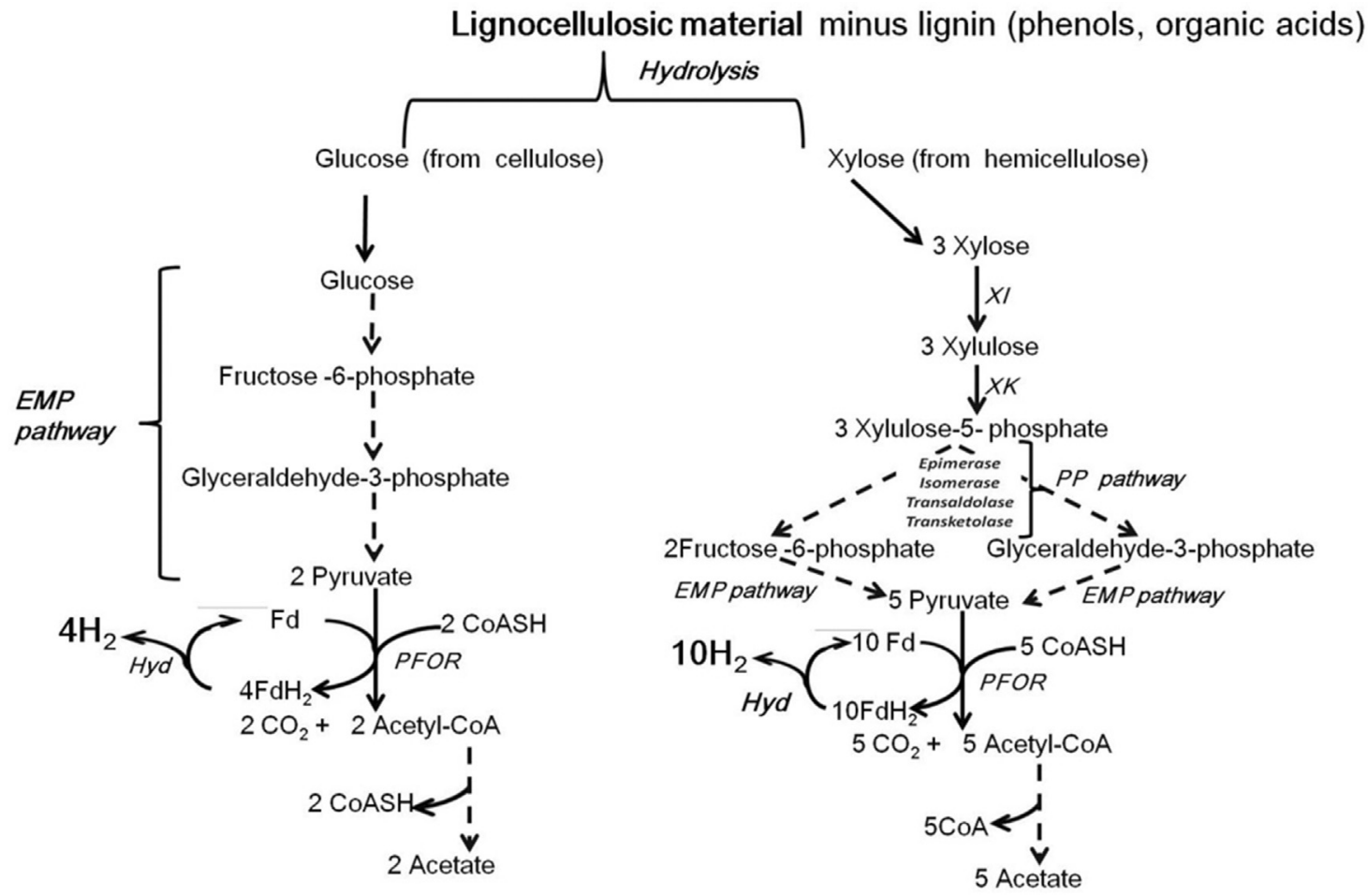

Figure 1 - Schematic view of the major metabolic pathways that lead to the production of $\mathrm{H}_{2}, \mathrm{CO}_{2}$, and acetate from the carbohydrate components obtained from the hydrolysis of lignocellulosic materials. EMP, Embden-Meyerhoff-Parma; Fd, oxidized ferredoxin; FdH ${ }_{2}$, reduced ferredoxin; Hyd, hydrogenase; PFOR, pyruvate: ferredoxin oxyreductase; PP, pentose phosphate; XI, xylose isomerase; XK, xylulokinase. The dashed arrows indicate multisteps of a metabolic pathway.

xin-dependent hydrogenase (Hyd) will produce $\mathrm{H}_{2}, \mathrm{CO}_{2}$, and acetate.

According to the Figure 1, glucose is converted to pyruvate, from which $\mathrm{H}_{2}, \mathrm{CO}_{2}$, and acetate are produced, as outlined above. It is noteworthy that for both carbohydrates, the consumption of reducing power to generate butyrate instead of acetate reduces the $\mathrm{H}_{2}$ yield.

To produce $\mathrm{H}_{2}$ by fermentation, it is possible to use (1) lignocellulosic materials without any chemical or biological pretreatment, (2) lignocellulosic materials after a pretreatment step, or (3) hydrolysates of lignocellulosic materials that normally originate after a pretreatment step followed by enzymatic hydrolysis. Another approach is to conduct simultaneous saccharification and fermentation (SSF), which consists in adding a hydrolytic enzyme(s) or microorganisms to a fermentation vessel (Quemeneur et al., 2012a).

\section{Pretreatment of Lignocellulosic Materials for Fermentative $\mathrm{H}_{2}$ Production}

The complex nature of lignocellulosic substrates may adversely affect their biodegradability. Therefore, prehydrolysis, often referred to as pretreatment, is required to alter the structure of lignocellulosic biomass to make the sugars available for fermentation (Ren et al., 2009, Levin et al., 2009). Carbohydrate polymers (cellulose and hemi- cellulose) and lignin are the main components of lignocellulosic materials (Rezende et al., 2011; Mood et al., 2013). Agricultural residues such as wheat straw, corn stalk, sugarcane bagasse, and rice straw contain approximately $32-47 \%$ cellulose, $19-27 \%$ hemicellulose, and 5-24\% lignin (Sun and Cheng, 2002). Although hemicellulose and lignin are minor components, they protect cellulose. Hence, it is necessary to hydrolyze these components, to efficiently use the cellulose (Mosier et al., 2005; Rezende et al., 2011). Thus, appropriate pretreatment steps reduce the cellulose crystallinity and/or polymerization degree and selectively remove hemicellulose and lignin to make carbohydrates from lignocellulosic materials accessible for enzymatic hydrolysis (Mood et al., 2013; Monlau et al., 2013a).

The main pretreatment methods rely on mechanical, physical, chemical, and biological techniques or a combination thereof (Alvira et al., 2010; Guo et al., 2010b; Ogeda and Petri, 2010). These methods serve to prepare lignocellulosic materials for bioethanol production mainly, but most of them also find application in fermentative $\mathrm{H}_{2}$ production (Guo et al., 2010a; Mood et al., 2013; Monlau et al., 2013a).

Physicochemical pretreatment includes steam explosion, steam explosion with ammonium, use of organic solvents and supercritical fluids, and use of diluted acids 
and/or bases (Mosier et al., 2005; Vargas Betancur and Pereira Jr, 2010; Monlau et al., 2013b). Biological pretreatment relies on the ability of fungi and bacteria to produce enzymes such as lignin peroxidase and laccase, and hemicellulase, which help to remove lignin and hemicellulose from the lignocellulosic matrix, respectively (Ogeda and Petri, 2010).

Various methods for pretreating lignocellulosic material exist; however, it is essential to select a method that minimizes carbohydrate degradation and avoids the formation of inhibitory compounds that are toxic to fermentative microorganisms (Alriksson et al., 2011; Rezende et al., 2011; Jonsson et al., 2013). Pretreatment at high temperatures rapidly degrades hemicellulose pentoses and to a lesser extent hexoses, producing acetic acid and furfurals, which constitute potential fermentation inhibitors (Alriksson et al., 2011; Jonsson et al., 2013).

Figure 2 shows the main carbohydrate degradation products from hemicelluloses and cellulose hydrolysis, i.e., xylose and glucose, as well as furfural, hydroxymethylfurfural (HMF), and organic acids, such as formic and acetic acid (Palmqvist and Hahn-Hagerdal, 2000; Jonsson et al., 2013).

Furfural originates from pentose dehydration; its concentration in the liquid phase increases with rising pretreatment temperature, acid concentration, or pretreatment time (Chen et al., 2013). Furfural may react further, to yield formic acid, or it may polymerize. Hydroxymethylfurfural (HMF) stems from the dehydration of hexoses such as glucose; it can further react to yield levulinic and formic acid (Palmqvist and Hahn-Hagerdal, 2000; Chen et al., 2013; Jonsson et al., 2013). These inhibitors may interfere with cell functions and osmotic pressure; they can even directly inhibit the acid fermentation pathway (Palmqvist and Hahn-Hagerdal, 2000).

Acetic acid is an inhibitory substance that also exists in hydrolysates. It is formed by the hydrolysis of acetyl groups in hemicellulose and, to some extent, lignin (Klinke et al., 2004). In the undissociated form, acetic acid can pen- etrate the cell membrane and inhibit product formation, disrupting the $\mathrm{pH}$ balance at high concentration, inhibiting cell growth or even killing cells (Klinke et al., 2002). However, some strains can use acetic acid as a substrate to produce $\mathrm{H}_{2}$ (Matsumoto and Nishimura, 2007; Xu et al., 2010).

Aromatics may arise in hydrolysates depending on the type of pretreatment applied and on the ratio of p-coumaryl alcohol, coniferyl, and sinapyl alcohol, the main lignin monomers. Pretreatment can transform lignin into a complex mixture of low-molecular-weight or "monomeric" phenolic compounds, especially by acid impregnation (Klinke et al., 2004; Chen et al., 2013). Phenolic compounds are well known for being toxic to microbial cells. They bear carboxyl, formyl, and hydroxyl groups, which increase the fluidity of the membrane and affect its permeability (Ren et al., 2009).

In summary, the pretreatment of lignocellulosic material to use it as a substrate for producing $\mathrm{H}_{2}$ may generate fermentation inhibitors as well as other unusual substrates, such as pentose (xylose) and/or oligosaccharides (Maintinguer et al., 2011; Quemeneur et al., 2012b), which is a major drawback.

The use of xylose as a substrate appears to be less problematic than the presence of inhibitory compounds because xylose can be metabolized as illustrated in Figure 1. Indeed a series of $\mathrm{H}_{2}$-producing microorganisms, such as Clostridium spp. (Maintinguer et al., 2011); Enterobacter spp. CN1 (Long et al., 2010); and the thermophiles Thermoanaerobacterium saccharolyticum (Ren et al., 2008; Shaw et al., 2008), Thermotoga neapolitana DSM 4359 (Ngo et al., 2012), Caldicellulosiruptor saccharolyticus (de Vrije et al., 2009) and Thermoanaerobacterium thermosaccharolyticum (Khamtib and Reungsang, 2012), can consume and produce hydrogen from xylose. Ren et al. (2008) reported that T. saccharolyticum W16 can ferment a mixture of glucose and xylose with a $\mathrm{H}_{2}$ yield of up to $2.37 \mathrm{~mol}$ of $\mathrm{H}_{2} / \mathrm{mol}$ of substrate.

However, inhibitors such as furan derivatives and phenolic compounds negatively affect $\mathrm{H}_{2}$ production by

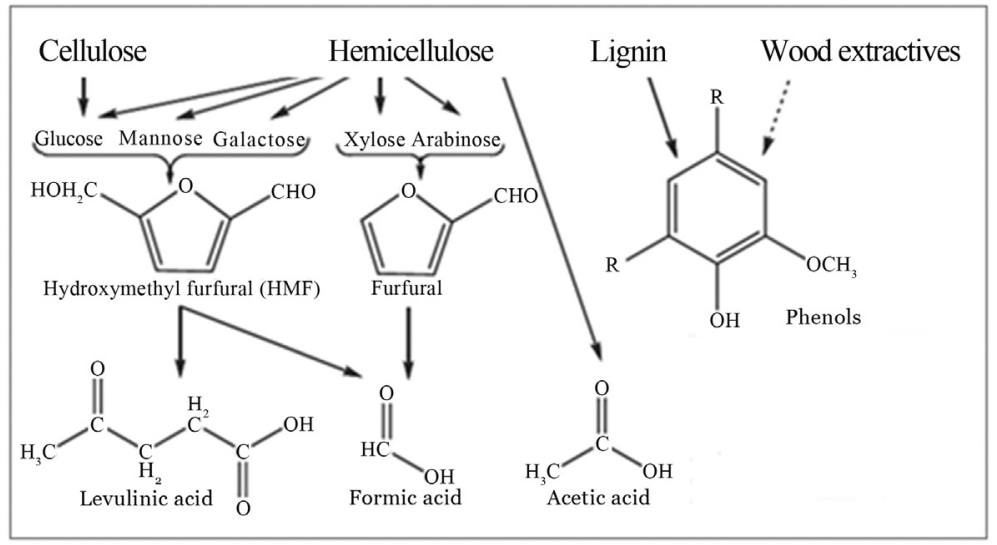

Figure 2 - Products and subproducts from the pretreatment of lignocellulosic materials (modified from Jonsson et al., 2013). 
mixed cultures. According to Quéméneur et al. (2012), furans exert a more negative effect than that induced by phenolic compounds. These authors found that Clostridium beijerinckii strains resisted these inhibitors better than other clostridial and non-clostridial bacteria did; therefore, C. beijerinckii is a promising microorganism for $\mathrm{H}_{2}$ production from lignocellulosic hydrolysates. Tai et al. (2010) observed that higher phenol concentrations $(1 \mathrm{~g} / \mathrm{L})$ significantly inhibited $C$. butyricum metabolism. Nevertheless, no metabolic inhibition or co-degradation occurred at concentrations of approximately $0.6 \mathrm{~g} / \mathrm{L}$. Veeravalli et al. (2013) observed that furans affected fermentative $\mathrm{H}_{2}$ production by a mixed anaerobic culture. Furan levels of up to $1 \mathrm{~g} / \mathrm{L}$ favored propionate and ethanol generation, decreasing $\mathrm{H}_{2}$ production.

In conclusion, the main limitation of using pretreated lignocellulosic materials in fermentative $\mathrm{H}_{2}$ production is the presence of these inhibitors.

\section{$\mathrm{H}_{2}$ Production From Non-Pretreated Lignocellulosic Materials}

Because pretreatment processes are expensive and can produce inhibitory compounds, it would be beneficial to avoid pretreatment and directly convert lignocellulosic materials to $\mathrm{H}_{2}$ (Levin et al., 2009; Raj et al., 2012).

Only a few reports concerning the production of $\mathrm{H}_{2}$ from untreated lignocellulosic feedstocks exist in the literature (Ren et al., 2009), and most of them involve thermophilic microorganisms. For example, Clostridium thermocellum ATCC 27405 and C. saccharolyticus DSM 8903 can hydrolyze cellulose and hemicellulose to produce $\mathrm{H}_{2}$ (Raj et al., 2012).

C. saccharolyticus can produce $\mathrm{H}_{2}$ directly from mechanically comminuted switchgrass without any chemical or biological pretreatment (Talluri et al., 2013).

Some authors have resorted to co-cultures that allow for the use of lignocellulosic materials as substrates. Wang et al. (2008) reported that a co-culture consisting of Clostridium acetobutylicum and Ethanoigenens harbinense effectively hydrolyzed cellulose and produced $\mathrm{H}_{2}$ from microcrystalline cellulose. Li and Liu (2012) developed a co-culture of $C$. thermocellum and $C$. thermosaccharolyticum, to improve hydrogen production via the thermophilic fermentation of cornstalk waste. The authors achieved a hydrogen yield of $68.2 \mathrm{~mL}$ of $\mathrm{H}_{2} / \mathrm{g}$ of cornstalk, $94.1 \%$ higher than the yield obtained using a monoculture of $C$. thermocellum.

Table 1 lists results for fermentative $\mathrm{H}_{2}$ production from lignocellulosic materials without any chemical pretreatment, the employed inocula, and the $\mathrm{H}_{2}$ yield obtained from these substrates. The results are presented as maximum assessed production yield, as indicated by the authors; when possible, we converted the data and expressed them as maximum calculated production yield ( $\mathrm{mmol}$ of $\mathrm{H}_{2} / \mathrm{g}$ of substrate) for comparison. All the wastes included in Table 1 were milled before being assayed.

The temperature clearly affected the fermentative $\mathrm{H}_{2}$ production yield from lignocellulosic residues. Most of the studies that used untreated lignocellulosic materials employed thermophilic conditions $(10, \mathrm{n}=14)$ to provide yields approximately $75 \%$ higher than those obtained under mesophilic conditions. Although most studies employed a mixed culture as an inoculum, C. thermocellum and T. thermosaccharolyticum, previously known as $C$. thermosaccharolyticum were the thermophilic microorganisms most frequently employed to produce $\mathrm{H}_{2}$ from untreated feedstock.

The untreated raw materials presented in Table 1 afforded an average maximum calculated $\mathrm{H}_{2}$ production yield of 2.17 ( \pm 1.84$) \mathrm{mmol}$ of $\mathrm{H}_{2} / \mathrm{g}$ of substrate; yields ranged from 0.12 to $11.2 \mathrm{mmol}$ of $\mathrm{H}_{2} / \mathrm{g}$ of substrate. The only study on switchgrass furnished the highest yield - $11.2 \mathrm{mmol}$ of $\mathrm{H}_{2} / \mathrm{g}$ of substrate (Talluri et al., 2013). When we excluded this study from the calculations, the average $\mathrm{H}_{2}$ production yield from untreated lignocellulosic substrates decreased to $1.41( \pm 1.02) \mathrm{mmol} \mathrm{H}_{2} / \mathrm{g}$, where the highest average yield observed was that obtained for cornstalk - $2.16( \pm 1.17)$ mmol of $\mathrm{H}_{2} / \mathrm{g}$.

\section{$\mathrm{H}_{2}$ Production From Pretreated Lignocellulosic Materials}

Although some studies on the direct conversion of lignocellulosic materials to $\mathrm{H}_{2}$ exist, most microorganisms require pretreated lignocellulosic material as a substrate to produce biohydrogen. The degree of pretreatment depends on the nature of the raw material and on the inoculated organism(s) (Ren et al., 2009).

Most pretreatment steps generate undesirable inhibitors, but they significantly enhance $\mathrm{H}_{2}$ production. Zhang et al. (2007) improved biohydrogen production from cornstalk after acidification and heat pretreatment. The authors achieved maximum cumulative $\mathrm{H}_{2}$ production of $150 \mathrm{~mL}$ of $\mathrm{H}_{2} / \mathrm{g}$ of VS after treating the substrate with $0.2 \%$ $\mathrm{HCl}$; this production was 50 times higher than the value obtained without pretreatment. Cornstalks treated with $\mathrm{NaOH}$ $(0.5 \%)$ furnished $57 \mathrm{~mL}$ of $\mathrm{H}_{2} / \mathrm{g}$ of VS, i.e., 19 -fold the initial value obtained for the raw material $\left(3 \mathrm{~mL}\right.$ of $\mathrm{H}_{2} / \mathrm{g}$ of VS) (Zhang et al., 2007).

Table 2 summarizes literature results concerning the use of pretreated lignocellulosic wastes, the pretreatment type, the inoculum, and the $\mathrm{H}_{2}$ yield obtained from these substrates. The results shown in Table 2 refer to the maximum assessed production yield, as indicated by the authors; when possible, we converted the data and expressed them as maximum calculated production yield $\left(\mathrm{mmol} \mathrm{H}_{2} / \mathrm{g}\right.$ of substrate) for comparison.

Acid and base pretreatment have been the pretreatments most frequently employed to prepare lignocellulosic 
Table 1 - Fermentative $\mathrm{H}_{2}$ production from lignocellulosic residues without pretreatment: employed inoculum and $\mathrm{H}_{2}$ yield obtained from these substrates.

\begin{tabular}{|c|c|c|c|c|c|}
\hline Feedstock & Inoculum & $\mathrm{T}\left({ }^{\circ} \mathrm{C}\right)$ & $\begin{array}{l}\text { Maximum assessed } \\
\text { production yield }^{\mathrm{a}}\end{array}$ & $\begin{array}{l}\text { Maximum calculated } \\
\text { production yield (mmol } \\
\left.\mathrm{H}_{2} / \mathrm{g} \text { of substrate) }\right)^{\mathrm{b}}\end{array}$ & Reference \\
\hline Cornstalk & C. thermocellum & 55 & $61.4 \mathrm{~mL}$ of $\mathrm{H}_{2} / \mathrm{g}$ & 2.28 & Cheng and Liu, 2012 \\
\hline Cornstalk & anaerobic digester sludge & 55 & $37.6 \mathrm{~mL}$ of $\mathrm{H}_{2} / \mathrm{g}$ & 1.40 & Cheng and Liu, 2012 \\
\hline Cornstalk & $\begin{array}{l}\text { mixed microflora from } \\
\text { rotted wood crumb }\end{array}$ & 60 & $115.3 \mathrm{~mL}$ of $\mathrm{H}_{2} / \mathrm{g}$ & 4.22 & Cao et al., 2012 \\
\hline Cornstalk & $\begin{array}{l}\text { C. thermocellum, } C \text {. } \\
\text { thermosaccharolyticum }\end{array}$ & 55 & $74.9 \mathrm{~mL}$ of $\mathrm{H}_{2} / \mathrm{g}$ & 2.78 & Li and Liu, 2012 \\
\hline Cornstalk & cow dung compost & 36 & $3 \mathrm{~mL}$ of $\mathrm{H}_{2} / \mathrm{g}$ & 0.12 & Zhang et al., 2007 \\
\hline $\begin{array}{l}\text { Mushroom cultiva- } \\
\text { tion waste }\end{array}$ & heated mixed cultures & 55 & $0.73 \mathrm{mmol}$ of $\mathrm{H}_{2} / \mathrm{g}$ & 0.73 & Lay et al., 2012 \\
\hline Grass (Reed canary) & $\begin{array}{l}\mathrm{H}_{2} \text {-microbial enrichment } \\
\text { culture }\end{array}$ & 35 & $0.19 \mathrm{mmol}$ of $\mathrm{H}_{2} / \mathrm{g}$ & 0.19 & Lakaniemi et al., 2011 \\
\hline Grass & $\begin{array}{l}\text { mixed cultures enriched } \\
\text { with } C \text {. pasteurianum }\end{array}$ & 35 & $4.39 \mathrm{~mL}$ of $\mathrm{H}_{2} / \mathrm{g}$ & 0.17 & Cui and Shen, 2012 \\
\hline Grass (switchgrass) & $\begin{array}{l}\text { C. saccharolyticus DSM } \\
8903\end{array}$ & 65 & $11.2 \mathrm{mmol}$ of $\mathrm{H}_{2} / \mathrm{g}$ & 11.2 & Talluri et al., 2013 \\
\hline Rice straw & T. neapolitana & 75 & $2.3 \mathrm{mmol}$ of $\mathrm{H}_{2} / \mathrm{g}$ & 2.3 & Nguyen et al., 2010 \\
\hline Rice straw & sewage sludge & 55 & $21 \mathrm{~mL}$ of $\mathrm{H}_{2} / \mathrm{g}$ & 0.78 & Kim et al, 2013 \\
\hline Wheat straw & $\begin{array}{l}\text { preheated anaerobic } \\
\text { sludge }\end{array}$ & 37 & $10.52 \mathrm{~mL}$ of $\mathrm{H}_{2} / \mathrm{g} \mathrm{VS}^{\mathrm{c}}$ & 0.41 & Quemeneur et al., 2012 (a) \\
\hline Wheat straw & C. saccharolyticus & 70 & $44.7 \mathrm{~mL}$ of $\mathrm{H}_{2} / \mathrm{g}$ & 1.59 & Ivanova et al., 2009 \\
\hline
\end{tabular}

${ }^{a}$ Maximum assessed production yields are the results presented by the authors.

'Maximum calculated production yields are results converted from authors' data determined according to the ideal gas equation considering a pressure of $1 \mathrm{~atm}$ and the absolute temperature used during $\mathrm{H}_{2}$ fermentation.

${ }^{\mathrm{c}} \mathrm{VS}$ : Volatile solids contained in the substrate.

materials for biohydrogen production - 11 and 6 studies, respectively, from the 21 publications presented in Table 2 have been reported. Enzymatic and/or biological pretreatment represent 3 of the 21 studies shown in Table 2. Only one study involved the use of temperature alone.

As indicated by the maximum calculated production yield data presented in Table 2, the biological pretreatment afforded the highest average yield $4.54( \pm 1.78) \mathrm{mmol}$ of $\mathrm{H}_{2} / \mathrm{g}$ of substrate compared with the acid and basic pretreatment $\left(2.94 \pm 1.85\right.$ and $2.41 \pm 1.52 \mathrm{mmol}$ of $\mathrm{H}_{2} / \mathrm{g}$ of substrate, respectively). Therefore, pretreatment effectiveness depended on the feedstock and pretreatment conditions, such as acid or base concentration, exposure time, and temperature.

According to Table 2, the average $\mathrm{H}_{2}$ production yield from pretreated material was 3.17 ( \pm 1.79$)$, ranging from 0.68 to $8.11 \mathrm{mmol}^{\circ} \mathrm{H}_{2} / \mathrm{g}$ of substrate for corn stover and cornstalk, respectively. Pretreated cornstalk furnished the highest average yield $4.74( \pm 1.80) \mathrm{mmol}$ of $\mathrm{H}_{2} / \mathrm{g}$ of substrate, which was approximately 2.2 times higher that yielded by untreated cornstalk $\left(2.17 \pm 1.84 \mathrm{mmol} \mathrm{H}_{2} / \mathrm{g}\right.$ of substrate, Table 1). Therefore, the pretreatment step enhances $\mathrm{H}_{2}$ production.
Most studies used a mixed culture of microorganisms previously enriched with $\mathrm{H}_{2}$-producing bacteria as an inoculum. The thermophilic T. thermosaccharolyticum was the pure culture most frequently employed in the studies using pretreated lignocellulosic wastes as substrates.

\section{$\mathrm{H}_{2}$ Production From Lignocellulosic Materials Hydrolysates}

The structural changes that prehydrolysis (pretreatment) promotes in a lignocellulosic matrix positively affect the subsequent enzymatic hydrolysis of lignocellulosic materials, increasing the saccharification yield (Ren et al., 2009). Several authors have used this strategy to increase the concentration of sugars in hydrolysates for $\mathrm{H}_{2}$ production (de Vrije et al., 2009; Cui et al., 2010; Luo et al., 2011; Pan et al., 2011; Monlau et al., 2013b). Pan et al. (2011) pretreated cornstalk containing $81.7 \%$ TVS with dilute acid, i.e., $1.5 \% \mathrm{H}_{2} \mathrm{SO}_{4}$, at $121{ }^{\circ} \mathrm{C}$ for $60 \mathrm{~min}$, followed by enzymatic hydrolysis at $52{ }^{\circ} \mathrm{C}, \mathrm{pH} 4.8$, with an enzyme loading of $9.4 \mathrm{IU} / \mathrm{g}$, to obtain a total soluble sugar content of $562.1 \pm 6.9 \mathrm{mg} / \mathrm{g}$ of TVS during the stages of hydrolysis. The maximum hydrogen yield from this hydrolysate using 
Table 2 - Fermentative $\mathrm{H}_{2}$ production from pretreated lignocellulosic residues, pretreatment type, inoculum, and $\mathrm{H}_{2}$ yield obtained from these substrates.

\begin{tabular}{|c|c|c|c|c|c|c|}
\hline Feedstock & Pretreatment & Inoculum & $\mathrm{T}\left({ }^{\circ} \mathrm{C}\right)$ & $\begin{array}{l}\text { Maximum assessed } \\
\text { production yield }^{\mathrm{a}}\end{array}$ & $\begin{array}{l}\text { Maximum calculated } \\
\text { production yield } \\
\left(\mathrm{mmol} \mathrm{H}_{2} / \mathrm{g} \text { of }\right. \\
\text { substrate })^{\mathrm{b}}\end{array}$ & Reference \\
\hline Beet pulp & $\begin{array}{l}\text { pH } 12 \text { with } \mathrm{NaOH} \text { for } \\
30 \text { min }\end{array}$ & anaerobic sludge & 35 & $\begin{array}{l}115.6 \mathrm{~mL} \text { of } \mathrm{H}_{2} / \mathrm{g} \\
\text { of } \mathrm{COD}\end{array}$ & - & Ozkan et al., 2011 \\
\hline Corn stalk & $\begin{array}{l}\text { Lime loading of } 0.10 \\
\mathrm{~g} / \mathrm{g} \text { of biomass for } 96 \mathrm{~h}\end{array}$ & $\begin{array}{l}\text { mixed microflora from rot- } \\
\text { ted wood crumb }\end{array}$ & 60 & $\begin{array}{l}155.4 \mathrm{~mL} \text { of } \mathrm{H}_{2} / \mathrm{g} \\
\text { of TVS }\end{array}$ & 5.69 & Cao et al., 2012 \\
\hline \multirow[t]{2}{*}{ Cornstalk } & $\begin{array}{l}\text { Phanerochaete } \\
\text { chrysosporium }\end{array}$ & T. thermosaccharolyticum & 50 & $89.3 \mathrm{~mL}$ of $\mathrm{H}_{2} / \mathrm{g}$ & 3.99 & Zhao et al., 2013 \\
\hline & Trichoderma viride & T. thermosaccharolyticum & 50 & $90.6 \mathrm{~mL}$ of $\mathrm{H}_{2} / \mathrm{g}$ & 4.04 & Zhao et al., 2013 \\
\hline Cornstalk & solid state enzymolysis & panda manure & 36 & $\begin{array}{l}205.5 \mathrm{~mL} \text { of } \mathrm{H}_{2} / \mathrm{g} \\
\text { of TVS }\end{array}$ & $8.11^{*}$ & Xing et al., 2011 \\
\hline Cornstalk & $\begin{array}{l}\mathrm{H}_{2} \mathrm{SO}_{4} 0.5 \% \text { at } 121^{\circ} \mathrm{C} \\
\text { for } 60 \mathrm{~min}\end{array}$ & $\begin{array}{l}\text { microwave irradiated cow } \\
\text { dung compost }\end{array}$ & 36 & $144.3 \mathrm{~mL}$ of $\mathrm{H}_{2} / \mathrm{g}$ & 6.44 & Song et al., 2012 \\
\hline Cornstalk & $\begin{array}{l}\mathrm{NaOH} \text { at } 120^{\circ} \mathrm{C} \text { for } \\
20 \mathrm{~min}\end{array}$ & anaerobic sludge & 55 & $45.7 \mathrm{~mL}$ of $\mathrm{H}_{2} / \mathrm{g}$ & 1.70 & $\begin{array}{l}\text { Cheng and } \\
\text { Liu, } 2012^{\text {(a) }}\end{array}$ \\
\hline Cornstalk & Fungal pretreatment & anaerobic sludge & 55 & $\begin{array}{l}54.1 \mathrm{~mL} \text { of } \mathrm{H}_{2} / \mathrm{g} \text { of } \\
\text { VS }\end{array}$ & $2.01 *$ & $\begin{array}{l}\text { Cheng and } \\
\text { Liu, } 2012^{\left({ }^{b}\right)}\end{array}$ \\
\hline Cornstalk & $\begin{array}{l}\text { Acidification } 0.2 \% \\
\mathrm{HCl}\end{array}$ & cow dung compost & 36 & $\begin{array}{l}149.69 \mathrm{~mL} \text { of } \mathrm{H}_{2} / \mathrm{g} \\
\text { of TVS }\end{array}$ & $5.90^{*}$ & Zhang et al., 2007 \\
\hline Corn stover & $\begin{array}{l}1.2 \% \mathrm{H}_{2} \mathrm{SO}_{4} / 2 \mathrm{~h} \text { and } \\
\text { steam explosion } \\
200{ }^{\circ} \mathrm{C} \text { for } 1 \mathrm{~min}\end{array}$ & dried sludge & 35 & $\begin{array}{l}184.71 \mathrm{~mL} \text { of } \\
\mathrm{H}_{2} / 10 \mathrm{~g} \\
(18.47 \mathrm{~mL} / \mathrm{g})\end{array}$ & 0.73 & Datar et al., 2007 \\
\hline Corn stover & $\begin{array}{l}\text { Microwave assisted } \\
\text { acid pretreatment } \\
\left(\mathrm{H}_{2} \mathrm{SO}_{4} 0.3 \mathrm{~N} \text { for }\right. \\
45 \mathrm{~min})\end{array}$ & anaerobic sludge & 55 & $18.22 \mathrm{~mL}$ of $\mathrm{H}_{2} / \mathrm{g}$ & 0.68 & $\begin{array}{l}\text { Liu and } \\
\text { Cheng, } 2010\end{array}$ \\
\hline \multirow[t]{2}{*}{ Grass } & $4 \% \mathrm{HCl}$ & anaerobic & 35 & $72.21 \mathrm{~mL}$ of $\mathrm{H}_{2} / \mathrm{g}$ & 2.86 & Cui and Shen 2012 \\
\hline & $0.5 \% \mathrm{NaOH}$ & mixed bacteria & 35 & $19.25 \mathrm{~mL}$ of $\mathrm{H}_{2} / \mathrm{g}$ & 0.86 & Cui and Shen 2012 \\
\hline $\begin{array}{l}\text { Grass (Reed ca- } \\
\text { nary) }\end{array}$ & $\begin{array}{l}3 \% \mathrm{HCl} \text { solution for } \\
90 \mathrm{~min} \text { at } 121{ }^{\circ} \mathrm{C}\end{array}$ & $\begin{array}{l}\mathrm{H}_{2} \text {-fermenting microbial } \\
\text { enrichment culture }\end{array}$ & 35 & $1.25 \mathrm{mmol}$ of $\mathrm{H}_{2} / \mathrm{g}$ & 1.25 & $\begin{array}{l}\text { Lakaniemi et } \\
\text { al., } 2011\end{array}$ \\
\hline Rapeseed stillage & $\begin{array}{l}\text { Alkaline peroxide with } \\
\text { steam treatment }\end{array}$ & digested manure & 55 & $79 \mathrm{~mL}$ of $\mathrm{H}_{2} / \mathrm{gVS}$ & $2.94 *$ & Luo et al., 2011 \\
\hline Rapeseed cake & $\begin{array}{l}\text { Alkaline peroxide with } \\
\text { steam treatment }\end{array}$ & digested manure & 55 & $24 \mathrm{~mL}$ of $\mathrm{H}_{2} / \mathrm{gVS}$ & $0.89 *$ & Luo et al., 2011 \\
\hline Rice straw & $\begin{array}{l}10 \% \text { ammonia and } \\
1.0 \% \mathrm{H}_{2} \mathrm{SO}_{4}\end{array}$ & T. neapolitana & 75 & $2.7 \mathrm{mmol}$ of $\mathrm{H}_{2} / \mathrm{g}$ & 2.70 & Nguyen et al., 2010 \\
\hline Sugarcane bagasse & $\begin{array}{l}0.5 \% \mathrm{H}_{2} \mathrm{SO}_{4} \text { for } \\
60 \mathrm{~min} \text { at } 121{ }^{\circ} \mathrm{C}\end{array}$ & C. butyricum & 37 & $\begin{array}{l}1.73 \mathrm{~mol} \text { of } \mathrm{H}_{2} / \mathrm{mol} \\
\text { sugar }\end{array}$ & - & Pattra et al., 2008 \\
\hline Sugarcane bagasse & $\begin{array}{l}\mathrm{H}_{2} \mathrm{SO}_{4} \text { at } 1 \% \text { for } \\
60 \text { min at } 121{ }^{\circ} \mathrm{C}\end{array}$ & preheated elephant dung & 37 & $\begin{array}{l}0.84 \mathrm{~mol}_{\text {of }} \mathrm{H}_{2} / \mathrm{mol} \\
\text { sugar }\end{array}$ & - & $\begin{array}{l}\text { Fangkum and } \\
\text { Reunsang, } 2011\end{array}$ \\
\hline Sugarcane bagasse & $\begin{array}{l}\mathrm{H}_{2} \mathrm{SO}_{4} \text { at } 1 \% \text { for } \\
60 \text { min at } 121{ }^{\circ} \mathrm{C}\end{array}$ & T. thermosaccharolyticum & 55 & $\begin{array}{l}1.12 \mathrm{~mol} \text { of } \mathrm{H}_{2} / \mathrm{mol} \\
\text { sugar }\end{array}$ & - & $\begin{array}{l}\text { Saripan and } \\
\text { Reungsang, } 2013\end{array}$ \\
\hline $\begin{array}{l}\text { Waste ground } \\
\text { wheat }\end{array}$ & $\begin{array}{l}\mathrm{H}_{2} \mathrm{SO}_{4}, \mathrm{pH} 3.0,90^{\circ} \mathrm{C} \\
\text { for } 15 \mathrm{~min}\end{array}$ & preheated anaerobic sludge & 37 & $946.2 \mathrm{~mL}$ & - & Sagnak et al., 2011 \\
\hline Wheat straw & $\mathrm{HCl}$ pretreated & cow dung compost & 36 & $\begin{array}{l}68.1 \mathrm{~mL} \text { of } \mathrm{H}_{2} / \mathrm{g} \\
\text { TVS }\end{array}$ & $3.04 *$ & Fan et al., 2006 \\
\hline Wheat straw & $\begin{array}{l}\text { Hydrothermic } 180^{\circ} \mathrm{C} \\
\text { for } 15 \mathrm{~min}\end{array}$ & preheated anaerobic sludge & 70 & $\begin{array}{l}7.36 \mathrm{mmol} \text { of } \mathrm{H}_{2} / \mathrm{g} \\
\text { sugars }\end{array}$ & - & $\begin{array}{l}\text { Kongjan et } \\
\text { al., } 2010\end{array}$ \\
\hline
\end{tabular}

${ }^{a}$ Maximum assessed production yields are the results as presented by the authors.

'Maximum calculated production yields results converted from authors' data calculated according to the ideal gas equation considering a pressure of 1 atm and the absolute temperature used during $\mathrm{H}_{2}$ fermentation. 
an anaerobic mixed culture was calculated in terms of grams of cornstalk (TVS) as $209.8 \mathrm{~mL}$ of $\mathrm{H}_{2} / \mathrm{g}$ of TVS.

Pretreatment followed by enzymatic hydrolysis is a very efficient method for saccharifying lignocellulosic substrates. However, depending on the type of substrate and pretreatment conditions employed, the hydrolysates could inhibit fermentative $\mathrm{H}_{2}$ production. Monlau et al. (2013b) verified that hydrolysates from sunflower stalks pretreated with dilute acid negatively affected $\mathrm{H}_{2}$-producing microflora. The dilute acid pretreatment condition that these authors employed $\left(170{ }^{\circ} \mathrm{C}, 1 \mathrm{~h}, 4 \mathrm{~g}\right.$ of $\mathrm{HCl} / 100 \mathrm{~g}$ of TS) was highly efficient in hydrolyzing hemicellulosic material because approximately $3.14 \mathrm{~g} / \mathrm{L}$ of xylose and only $0.28 \mathrm{~g} / \mathrm{L}$ of glucose emerged in the slurry. In addition to the amount of xylose, other byproducts arose - formate $(0.6 \mathrm{~g} / \mathrm{L})$ and acetate $(0.81 \mathrm{~g} / \mathrm{L})$, and furan derivatives such as furfural $(1.15 \mathrm{~g} / \mathrm{L})$ and HMF $(0.13 \mathrm{~g} / \mathrm{L})$. In a batch system inoculated with mixed microflora, $15 \%$ of this hydrolysate completely inhibited $\mathrm{H}_{2}$ production.

In a long-term experiment, Arreola-Vargas et al. (2013) observed that partial replacement of a synthetic medium containing glucose and xylose with an acid and with an enzymatic hydrolysate of oat straw, in a continuous reactor, diminished $\mathrm{H}_{2}$ production. The acid hydrolysate consisted mainly of glucose $1.5 \mathrm{~g} / \mathrm{L}$ and xylose $3.7 \mathrm{~g} / \mathrm{L}$ as well as phenolic compounds, such as HMF $(133.2 \mathrm{mg} / \mathrm{L})$, furfural $(0.6 \mathrm{mg} / \mathrm{L})$, and vanillin $(3.59 \mathrm{mg} / \mathrm{L})$. The enzymatic hydrolysate contained $3.8 \mathrm{~g} / \mathrm{L}$ of glucose and $1.3 \mathrm{~g} / \mathrm{L}$ of xylose, but no HMF, furfural, or vanillin. Both hydrolysates were used to feed an anaerobic sequencing batch reactor by gradually substituting the glucose/xylose medium with the hydrolysates. The substitution of glucose/xylose by the acid hydrolysate disaggregated the granules and interrupted the process. On the other hand, the replacement of the glucose/xylose medium with the enzymatic hydrolysate without fermentation inhibitors elicited $\mathrm{H}_{2}$ production. However, the $\mathrm{H}_{2}$ yield and production rate decreased from $2 \mathrm{~mol}$ of $\mathrm{H}_{2} / \mathrm{mol}$ of sugar and $278 \mathrm{~mL}$ of $\mathrm{H}_{2} / \mathrm{L}$.h to $0.81 \mathrm{~mol}$ of $\mathrm{H}_{2} / \mathrm{mol}$ of sugar and $29.6 \mathrm{~mL} \mathrm{H}_{2} /$ L.h, respectively, in going from the synthetic medium to the enzymatic hydrolysate (Arreola-Vargas et al., 2013).

Simultaneous saccharification and fermentation (SSF) has been successfully conducted to produce $\mathrm{H}_{2}$ from pretreated or even untreated lignocellulosic substrates by adding hydrolytic enzyme(s) or by seeding hydrolytic enzymes produced in the same fermentation vessel. Thus, in this approach, no pretreatments or only mild conditions for pretreating substrates are necessary, diminishing the formation of fermentation inhibitors (see Figure 2) because most saccharification occurs simultaneously with the fermentation (Lakshmidevi and Muthukumar, 2010; Quemeneur et al., 2012a; Zhao et al., 2013). For example, Quemeneur et al. (2012a) used a mixed culture of microorganisms and evaluated the efficiency of exogenous enzyme addition during fermentative $\mathrm{H}_{2}$ production from wheat straw. The authors used two experimental designs: a onestage system (direct enzyme addition) and a two-stage system (enzymatic hydrolysis prior to fermentation). $\mathrm{H}_{2}$ production from untreated wheat straw ranged from 5.18 to $10.52 \mathrm{~mL}$ of $\mathrm{H}_{2} / \mathrm{g}$ of $v \mathrm{~s} . \mathrm{H}_{2}$ production yields increased two-fold and ranged from 11.06 to $19.63 \mathrm{~mL}$ of $\mathrm{H}_{2} / \mathrm{g}$ of VS after the enzymatic treatment of the wheat straw. Direct addition of exogenous enzymes during one-stage dark fermentation was the best way to improve $\mathrm{H}_{2}$ production from lignocellulosic biomass.

Table 3 summarizes the lignocellulosic material hydrolysates used as substrates for fermentative $\mathrm{H}_{2}$ production, the pretreatment and enzymatic hydrolysis methods used, the source of inoculum or the microorganisms involved in the fermentation, and the process yields and/or rates. Results regarding $\mathrm{H}_{2}$ yields from hydrolysates are expressed in terms of mmol of $\mathrm{H}_{2} / \mathrm{mmol}$ of sugar or mmol of $\mathrm{H}_{2} / \mathrm{g}$ of substrate because it was not always possible to convert these units. In the last case, it was possible to compare data with the results of untreated and pretreated substrates (Table 1 and 2).

According to Table 3 the $\mathrm{H}_{2}$ production yields from hydrolysates ranged from 0.45 to $13.39 \mathrm{mmol}$ of $\mathrm{H}_{2} / \mathrm{g}$ of substrate, for wheat straw and sugarcane bagasse, respectively.

Cornstalk is the most often studied lignocellulosic substrate for $\mathrm{H}_{2}$ production. The average yield using a cornstalk hydrolysate for biohydrogen production is $5.93 \mathrm{mmol}$ of $\mathrm{H}_{2} / \mathrm{g}$ of substrate, which is approximately $270 \%$ and $25 \%$ higher than that afforded by the untreated ( $2.17 \mathrm{mmol}$ of $\mathrm{H}_{2} / \mathrm{g}$ of substrate) and pretreated cornstalk (4.74 $\mathrm{mmol}$ of $\mathrm{H}_{2} / \mathrm{g}$ of substrate), respectively. The results demonstrated that after pretreatment and/or hydrolysis, this substrate is potentially applicable in biohydrogen production.

Although sugarcane bagasse afforded the highest yield - $13.39 \mathrm{mmol}$ of $\mathrm{H}_{2} / \mathrm{g}$ of TVS; this figure represents the results obtained in only one study (Chairattanamanokorn et al., 2009). The average $\mathrm{H}_{2}$ production yield per mol of sugar of pretreated bagasse was $1.23 \mathrm{~mol}$ of $\mathrm{H}_{2} / \mathrm{mol}$ of glucose (Table 2); for the hydrolysates, this yield dropped to 1.12 (Table 3), demonstrating that $\mathrm{H}_{2}$ production from hydrolysates of this substrate was slightly lower.

Excluding the work of Chairattanamanokorn et al. (2009) with sugarcane bagasse, the average $\mathrm{H}_{2}$ production yield with sugarcane bagasse hydrolysates (Table 3) was $3.78 \pm 1.92 \mathrm{mmol}$ of $\mathrm{H}_{2} / \mathrm{g}, 20 \%$ higher compared with the average yields of pretreated substrates. However, this average $\mathrm{H}_{2}$ production yield was lower than that of biologically pretreated substrates, $4.54 \pm 1.78 \mathrm{mmol}$ of $\mathrm{H}_{2} / \mathrm{g}$. These results demonstrate the importance of avoiding the presence of inhibitors originating from chemical pretreatment methods. 
Table 3 - Fermentative $\mathrm{H}_{2}$ production from hydrolysates of lignocellulosic substrates according to pretreatment type and enzymatic hydrolysis, inocula, yields, and maximum production rate obtained from these substrates.

\begin{tabular}{|c|c|c|c|c|c|c|}
\hline Feedstock & Pretreatment/ hydrolysis & Inoculum & $\mathrm{T}\left({ }^{\circ} \mathrm{C}\right)$ & $\begin{array}{l}\text { Maximum } \\
\text { production yield } \\
\left({ }^{\left.\mathrm{a}, \mathrm{b}, \mathrm{b}^{*}\right)}\right.\end{array}$ & $\begin{array}{l}\text { Maximum pro- } \\
\text { duction rate } \\
\left.\text { (mmol of } \mathrm{H}_{2} / \mathrm{L} . \mathrm{h}\right)\end{array}$ & Reference \\
\hline Conifer pulp & $\begin{array}{l}55 \% \mathrm{H}_{2} \mathrm{SO}_{4} \text { at } 45{ }^{\circ} \mathrm{C} \text { for } 2 \\
\mathrm{~h}, \text { neutralized with } \\
\mathrm{Ca}(\mathrm{OH})_{2}\end{array}$ & $\begin{array}{l}\text { preheated anaerobic } \\
\text { sludge }\end{array}$ & 37 & $2.26^{\mathrm{a}}$ & nd & Nissilä et al., 2012 \\
\hline Corn stover & $\begin{array}{l}\text { Delignification with } 2 \% \\
\mathrm{NaOH}+\text { hydrolysis with } \\
\text { cellulase and xylanase }\end{array}$ & T. thermosaccharolyticum & 60 & nd & 11.2 & Ren et al., 2010 \\
\hline Cornstalk & $\begin{array}{l}\text { Dilute acid+enzymatic hy- } \\
\text { drolysis }\end{array}$ & $\begin{array}{l}\text { anaerobic mixed } \\
\text { microflora }\end{array}$ & 36 & $8.58^{\mathrm{b}}$ & nd & Pan et al., 2011 \\
\hline Cornstalk & $\begin{array}{l}\text { Fungal hydrolysis by } \\
\text { Trichoderma viride }\end{array}$ & $\begin{array}{l}\text { T. thermosaccharolyticum } \\
\text { W16 }\end{array}$ & 60 & $3.28^{\mathrm{b}}$ & nd & Zhao et al., 2013 \\
\hline \multirow[t]{2}{*}{ Miscanthus crop } & $\begin{array}{l}\text { Alkaline pretreatment at } \\
75^{\circ} \mathrm{C}+\text { enzymatic hydroly- } \\
\text { sis }\end{array}$ & C. saccharolyticus & 70 & $2.9^{\mathrm{a}}$ & 12.6 & de Vrije et al., 2009 \\
\hline & & T. neapolitana & 70 & $3.4^{\mathrm{a}}$ & 13.1 & de Vrije et al., 2009 \\
\hline Oat straw & $\mathrm{HCl}$ at $2 \%+90^{\circ} \mathrm{C}$ for $2 \mathrm{~h}$ & $\begin{array}{l}\text { two anaerobic sludg- } \\
\text { es, heated at } 100^{\circ} \mathrm{C} \text { for } 30 \\
\text { min. }\end{array}$ & 30 & $2.9^{\mathrm{a}}$ & 3.3 & Arriaga et al., 2011 \\
\hline Poplar leaves & $\begin{array}{l}\mathrm{HCl} \text { at } 4 \%+2 \% \\
\text { Viscozyme }\end{array}$ & anaerobic mixed bacteria & 35 & $1.78^{\mathrm{b}}$ & nd & Cui et al., 2010 \\
\hline Rapeseed & $\begin{array}{l}\text { Alkaline peroxide with } \\
\text { steam treatment }+ \text { celluclast } \\
\text { and } \beta \text {-glucosidase }\end{array}$ & digested manure & 55 & $3.38^{\mathrm{b}^{*}}$ & nd & Luo et al. \\
\hline Rice straw & $\begin{array}{l}\text { Alkaline pretreat- } \\
\text { ment }+ \text { Acinetobacter junii } \\
\text { F6- } 02 \text { enzymes }\end{array}$ & C. butyricum CGS5 & 37 & $0.76^{\mathrm{a}}$ & 1.05 & Lo et al., 2010 \\
\hline Sugarcane bagasse & $\begin{array}{l}\text { Pretreated with } \\
\mathrm{H}_{3} \mathrm{PO}_{4}+\text { Cellulomonas } u d a \\
\text { enzymes }\end{array}$ & C. butyricum CGS5 & 37 & $1.08^{\mathrm{a}}$ & nd & Lo et al., 2011 \\
\hline Sugarcane bagasse & $\begin{array}{l}\text { Alkaline and enzymatic } \\
\text { hydrolysis with cellulase } \\
\text { from Pseudomonas sp. }\end{array}$ & C. pasteurianum & 37 & $0.96^{\mathrm{a}}$ & 1.38 & $\begin{array}{l}\text { Cheng and } \\
\text { Chang, } 2011\end{array}$ \\
\hline Sugarcane bagasse & $\begin{array}{l}\mathrm{NaOH} 0.1 \mathrm{~mol} / \mathrm{L} \text { at } 100 \\
{ }^{\circ} \mathrm{C} \text { for } 2 \mathrm{~h} \text { and hydrolysis } \\
\text { with cellulase }\end{array}$ & $\begin{array}{l}\text { preheated anaerobic } \\
\text { sludge }\end{array}$ & 35 & $13.4^{\mathrm{b}^{*}}$ & $0.28^{\mathrm{c}}$ & $\begin{array}{l}\text { Chairattanamanokor } \\
\text { n et al., } 2009\end{array}$ \\
\hline Sunflower stalks & $\begin{array}{l}\mathrm{HCl} 4 \mathrm{~g} \text { at } 170{ }^{\circ} \mathrm{C} \text { for } 1 \\
\mathrm{~h} / 100 \mathrm{gTS}\end{array}$ & $\begin{array}{l}\text { preheated anaerobic } \\
\text { sludge }\end{array}$ & 35 & $2.04^{\mathrm{a}}$ & nd & Monlau et al., 2013 $3^{(\mathrm{b})}$ \\
\hline $\begin{array}{l}\text { Sweet sorghum ba- } \\
\text { gasse }\end{array}$ & $\begin{array}{l}\text { Pretreatment with } \\
\mathrm{NaOH}+\text { cellulase }\end{array}$ & C. saccharolyticus & 72 & $2.6^{\mathrm{a}}$ & $10.2-10.6$ & $\begin{array}{l}\text { Panagiotopoulos et } \\
\text { al, } 2010\end{array}$ \\
\hline Wheat straw & SSF (acid+enzymatic) & anaerobic sludge & 36 & $5.56^{\mathrm{b}^{*}}$ & nd & Nasirian et al., 2011 \\
\hline Wheat straw & $\begin{array}{l}\text { Ozone and simultaneous } \\
\text { enzymatic hydrolysis }\end{array}$ & $\begin{array}{l}\text { preheated cow manure and } \\
\text { pond sediment preheated }\end{array}$ & 35 & $3.2^{\mathrm{b}}$ & nd & Wu et al., 2013 \\
\hline \multirow[t]{2}{*}{ Wheat straw } & $\begin{array}{l}\text { SSF (Trichoderma }+ \text { fer- } \\
\text { mentation) }\end{array}$ & & 37 & $0.80^{\mathrm{b*}}$ & nd & $\begin{array}{l}\text { Quemeneur et } \\
\text { al., 2012 }\end{array}$ \\
\hline & $\begin{array}{l}\text { SSF (acid+enzymatic } \\
\text { saccharification prior to } \\
\text { fermentation) }\end{array}$ & $\begin{array}{l}\text { preheated anaerobic } \\
\text { sludge }\end{array}$ & 37 & $0.45^{\mathrm{b}^{*}}$ & nd & $\begin{array}{l}\text { Quemeneur et } \\
\text { al., 2012 }\end{array}$ \\
\hline
\end{tabular}

${ }^{a}$ Maximum production yield in terms of mmol of $\mathrm{H}_{2} / \mathrm{mmol}$ of sugar.

${ }^{\mathrm{b}}$ Maximum production yield in terms of $\mathrm{mmol}$ of $\mathrm{H}_{2} / \mathrm{g}$ of substrate.

${ }^{b *}$ Maximum production yield in terms of $\mathrm{mmol}$ of $\mathrm{H}_{2} / \mathrm{g}$ of total volatile solids (TVS) or volatile solids (VS) contained in the substrate.

${ }^{c}$ Maximum production rate in terms of $\mathrm{mmol}$ of $\mathrm{H}_{2} / \mathrm{h} . \mathrm{g}$ TVS.

nd: not determined. 


\section{Conclusions and Perspectives}

Based on this review, converting agroindustrial lignocellulosic substrates to $\mathrm{H}_{2}$ by fermentative microorganisms is a feasible solution for producing $\mathrm{H}_{2}$ sustainably. However, additional research into the pretreatment of lignocellulosic wastes for biohydrogen production is desirable to improve the yield and make the process economically viable. Efforts to control the formation (or removal) of toxic compounds (such as furan derivatives, phenolics, and organic acids, formed during the chemical pretreatment) are necessary because these could clearly inhibit $\mathrm{H}_{2}$ fermentation. Biological pretreatment methods afford higher $\mathrm{H}_{2}$ yields from lignocellulosic materials because they do not produce inhibitors.

The development of microbial strains or consortia resistant to inhibitors remains an important research area. Moreover, the discovery of novel $\mathrm{H}_{2}$-producing microorganisms able to use lignocellulosic derivatives is associated with different environmental conditions, particularly high temperatures.

Currently, results have shown that corn stalk submitted to a pretreatment step and/or hydrolysis furnishes a higher average yield of biohydrogen production than that afforded by other agroindustrial lignocellulosic substrates. Exploring other microorganisms and optimizing the pretreatment and hydrolysis conditions can make the use of this substrate and other agroindustrial residues a sustainable way to produce clean $\mathrm{H}_{2}$.

\section{Acknowledgments}

$$
\text { FAPESP (2010-2010/11901-0), CNPq. }
$$

\section{References}

Alriksson B, Cavka A, Jonsson L (2011) Improving the fermentability of enzymatic hydrolysates of lignocellulose through chemical in-situ detoxification with reducing agents. Bioresour Technol 102:1254-1263.

Alvira P, Tomás-Pejó E, Ballesteros M et al. (2010) Pretreatment technologies for an efficient bioethanol production process based on enzymatic hydrolysis: A review. Bioresour Technol 101:4851-4861.

Amaro HM, Macedo AC, Xavier Malcata F (2012) Microalgae: An alternative as sustainable source of biofuels? Energy 44:158-166.

Arreola-Vargas J, Celis LB, Buitrón G et al. (2013) Hydrogen production from acid and enzymatic oat straw hydrolysates in an anaerobic sequencing batch reactor: Performance and microbial population analysis. Int $\mathrm{J}$ Hydrogen Energy 38:13884-13894.

Arriaga S, Rosas I, Alatriste-Mondragón F et al. (2011) Continuous production of hydrogen from oat straw hydrolysate in a biotrickling filter. Int J Hydrogen Energy 36:3442-3449.

Cao GL, Guo WQ, Wang AJ et al. (2012) Enhanced cellulosic hydrogen production from lime-treated cornstalk wastes using thermophilic anaerobic microflora. Int J Hydrogen Energy 37:13161-13166.
Cao G, Ren N, Wang A et al. (2009) Acid hydrolysis of corn stover for biohydrogen production using Thermoanaerobacterium thermosaccharolyticum W16. Int J Hydrogen Energy 34:7182-7188.

Chairattanamanokorn $\mathrm{P}$, Penthamkeerati $\mathrm{P}$, Reungsang A et al. (2009) Production of biohydrogen from hydrolyzed bagasse with thermally preheated sludge. Int J Hydrogen Energy 34:7612-7617.

Chaubey R, Sahu S, James OO et al. (2013) A review on development of industrial processes and emerging techniques for production of hydrogen from renewable and sustainable sources. Renew Sust Energ Rev 23:443-462.

Chen R, Wang YZ, Liao Q et al. (2013) Hydrolysates of lignocellulosic materials for biohydrogen production. Bmb Reports 46:244-251.

Cheng CL, Chang JS (2011) Hydrolysis of lignocellulosic feedstock by novel cellulases originating from Pseudomonas sp. CL3 for fermentative hydrogen production. Bioresour Technol 102:8628-8634.

Cheng CL, Lo YC, Lee KS et al. (2011) Biohydrogen production from lignocellulosic feedstock. Bioresour Technol 102:8514-8523.

Cheng XY, Li Q, Liu CZ (2012) Coproduction of hydrogen and methane via anaerobic fermentation of cornstalk waste in continuous stirred tank reactor integrated with up-flow anaerobic sludge bed. Bioresour Technol 114:327-333.

Cheng XY, Liu CZ (2012a) Enhanced coproduction of hydrogen and methane from cornstalks by a three-stage anaerobic fermentation process integrated with alkaline hydrolysis. Bioresour Technol 104:373-379.

Cheng XY, Liu CZ (2012b) Fungal pretreatment enhances hydrogen production via thermophilic fermentation of cornstalk. Appl Energy 91:1-6.

Cui M, Shen J (2012) Effects of acid and alkaline pretreatments on the biohydrogen production from grass by anaerobic dark fermentation. Int J Hydrogen Energy 37:1120-1124.

Cui M, Yuan Z, Zhi X et al. (2010) Biohydrogen production from poplar leaves pretreated by different methods using anaerobic mixed bacteria. Int J Hydrogen Energy 35:4041-4047.

Das D, Veziroglu TN (2008) Advances in biological hydrogen production processes. Int J Hydrogen Energy 33:6046-6057.

Datar R, Huang J, Maness P-C et al. (2007) Hydrogen production from the fermentation of corn stover biomass pretreated with a steam-explosion process Int $\mathrm{J}$ Hydrogen Energy 32:932-939.

de Vrije T, Bakker RR, Budde MAW et al. (2009) Efficient hydrogen production from the lignocellulosic energy crop Miscanthus by the extreme thermophilic bacteria Caldicellulosiruptor saccharolyticus and Thermotoga neapolitana. Biotechnol Biofuels 2,12. http://www.biotechnologyforbiofuels.com/content/2/1/12

Elsharnouby O, Hafez H, Nakhla G et al. (2013) A critical literature review on biohydrogen production by pure cultures. Int J Hydrogen Energy 38:4945-4966.

Fan YT, Zhang YH, Zhang SF et al. (2006) Efficient conversion of wheat straw wastes into biohydrogen gas by cow dung compost. Bioresour Technol 97:500-505.

Fangkum A, Reungsang A (2011) Biohydrogen production from sugarcane bagasse hydrolysate by elephant dung: Effects of initial $\mathrm{pH}$ and substrate concentration. Int J Hydrogen Energy 36:8687-8696. 
Guo XM, Trably E, Latrille E et al. (2010a) Hydrogen production from agricultural waste by dark fermentation: A review. Int J Hydrogen Energy 35:10660-10673.

Guo Y, Kim S, Sung S et al. (2010b) Effect of ultrasonic treatment of digestion sludge on bio-hydrogen production from sucrose by anaerobic fermentation. Int J Hydrogen Energy 35:3450-3455.

Haghighi Mood S, Hossein Golfeshan A, Tabatabaei M et al. (2013) Lignocellulosic biomass to bioethanol, a comprehensive review with a focus on pretreatment. Renew Sust Energ Rev 27:77-93.

Hay JXW, Wu TY, Juan JC et al. (2013) Biohydrogen production through photo fermentation or dark fermentation using waste as a substrate: Overview, economics, and future prospects of hydrogen usage. Biofuels Bioprod Bioref 7:334-352.

Ho KL, Lee DJ, Su A et al. (2012) Biohydrogen from lignocellulosic feedstock via one-step process. Int J of Hydrogen Energy 37:15569-15574.

Ivanova G, Rakhely G, Kovacs KL (2009) Thermophilic biohydrogen production from energy plants by Caldicellulosiruptor saccharolyticus and comparison with related studies. Int J Hydrogen Energy 34:3659-3670.

Jonsson L, Alriksson B, Nilvebrant N-O (2013) Bioconversion of lignocellulose: inhibitors and detoxification. Biotechnol Biofuels 6:16.

Kaparaju P, Serrano M, Angelidaki I (2009) Effect of reactor configuration on biogas production from wheat straw hydrolysate. Bioresour Technol 100:6317-6323.

Kapdan IK, Kargi F (2006) Bio-hydrogen production from waste materials Enz Microb Technol 38:569-582.

Khamtib S, Reungsang A (2012) Biohydrogen production from xylose by Thermoanaerobacterium thermosaccharolyticum KKU19 isolated from hot spring sediment. Int J Hydrogen Energy 37:12219-12228.

Kim M, Liu C, Noh JW et al. (2013) Hydrogen and methane production from untreated rice straw and raw sewage sludge under thermophilic anaerobic conditions. Int J Hydrogen Energy 38:8648-8656.

Klinke H, Ahring B, Schmidt A et al. (2002) Characterization of degradation products from alkaline wet oxidation of wheat straw. Bioresour Technol 82:15-26.

Klinke HB, Thomsen AB, Ahring BK (2004) Inhibition of ethanol-producing yeast and bacteria by degradation products produced during pre-treatment of biomass. Appl Microbiol Biotechnol 66:10-26.

Kongjan P, Angelidaki I (2010) Extreme thermophilic biohydrogen production from wheat straw hydrolysate using mixed culture fermentation: Effect of reactor configuration. Bioresour Technol 101:7789-7796.

Kongjan P, O-Thong S, Kotay M et al. (2010) Biohydrogen Production From Wheat Straw Hydrolysate by Dark Fermentation Using Extreme Thermophilic Mixed Culture. Biotechnol Bioeng 105:899-908.

Kotay SM, Das D (2008) Biohydrogen as a renewable energy resource - Prospects and potentials. Int J Hydrogen Energy 33:258-263.

Kothari R, Singh DP, Tyagi VV et al. (2012) Fermentative hydrogen production - An alternative clean energy source. Renew Sust Energ Rev 16:2337-2346.
Lakaniemi AM, Koskinen PEP, Nevatalo LM et al. (2011) Biogenic hydrogen and methane production from reed canary grass. Biomass Bioenergy 35:773-780.

Lay CH, Sung IY, Kumar G et al. (2012) Optimizing biohydrogen production from mushroom cultivation waste using anaerobic mixed cultures. Int J Hydrogen Energy 37:16473-16478.

Levin DB, Carere CR, Cicek N et al. (2009) Challenges for biohydrogen production via direct lignocellulose fermentation. Int J Hydrogen Energy 34:7390-7403.

Levin DB, Pitt L, Love M (2004) Biohydrogen production: prospects and limitations to practical application. Int J Hydrogen Energy 29:173-185.

Li C, Fang H (2007) Fermentative hydrogen production from wastewater and solid wastes by mixed cultures. Crit Rev Environ Sci Technol 37:1-39.

Li Q, Liu CZ (2012) Co-culture of Clostridium thermocellum and Clostridium thermosaccharolyticum for enhancing hydrogen production via thermophilic fermentation of cornstalk waste. Int J Hydrogen Energy 37:10648-10654.

Li YC, Liu YF, Chu CY et al. (2012) Techno-economic evaluation of biohydrogen production from wastewater and agricultural waste. Int J Hydrogen Energy 37:15704-15710.

Lin CY, Lay CH, Sen B et al. (2012) Fermentative hydrogen production from wastewaters: A review and prognosis. Int J Hydrogen Energy 37:15632-15642.

Lin Y, Tanaka S (2006) Ethanol fermentation from biomass resources: current state and prospects. Appl Microbiol Biotechnol 69:627-642.

Liu CZ, Cheng XY (2010) Improved hydrogen production via thermophilic fermentation of corn stover by microwaveassisted acid pretreatment. Int J Hydrogen Energy 35:89458952.

Lo YC, Lu WC, Chen CY et al. (2010) Dark fermentative hydrogen production from enzymatic hydrolysate of xylan and pretreated rice straw by Clostridium butyricum CGS5. Bioresour Technol 101:5885-5891.

Lo YC, Su YC, Cheng CL et al. (2011) Biohydrogen production from pure and natural lignocellulosic feedstock with chemical pretreatment and bacterial hydrolysis. Int J Hydrogen Energy 36:13955-13963.

Long C, Cui J, Liu Z et al. (2010) Statistical optimization of fermentative hydrogen production from xylose by newly isolated Enterobacter sp CN1. Int J Hydrogen Energy 35:6657-6664.

Luo G, Talebnia F, Karakashev D et al. (2011). Enhanced bioenergy recovery from rapeseed plant in a biorefinery concept. Bioresour Technol 102:1433-1439.

Maintinguer SI, Fernandes BS, Duarte ICS (2011) Fermentative hydrogen production with xylose by Clostridium and Klebsiella species in anaerobic batch reactors. Int J Hydrogen Energy 36:13508-13517.

Martin del Campo JS, Rollin J, Myung S et al. (2013) High-yield production of dihydrogen from xylose by using a synthetic enzyme cascade in a cell-free system. Angew Chem Int Ed 52:1-5.

Matsumoto M, Nishimura Y (2007) Hydrogen production by fermentation using acetic acid and lactic acid. J Biosc Bioeng 103:236-241.

Monlau F, Barakat A, Trably E et al. (2013a) Lignocellulosic Materials Into Biohydrogen and Biomethane: Impact of Struc- 
tural Features and Pretreatment. Crit Rev Env Sci Technol 43:260-322.

Monlau F, Aemig Q, Trably E et al. (2013b) Specific inhibition of biohydrogen-producing Clostridium sp after dilute-acid pretreatment of sunflower stalks. Int $\mathrm{J}$ Hydrogen Energy 38:12273-12282.

Mood SH, Golfeshan AH, Tabatabaei M et al. (2013) Lignocellulosic biomass to bioethanol, a comprehensive review with a focus on pretreatment. Renew Sust Energy Rev 27:77-93

Mosier N, Wyman C, Dale B et al. (2005) Features of promising technologies for pretreatment of lignocellulosic biomass. Bioresour Technol 96:673-686.

Nasirian N, Almassi M, Minaei S et al. (2011) Development of a method for biohydrogen production from wheat straw by dark fermentation. Int J Hydrogen Energy 36:411-420.

Ngo TA, Nguyen TH, Bui BTV (2012) Thermophilic fermentative hydrogen production from xylose by Thermotoga neapolitana DSM 4359. Renew Energy 37:174-179.

Nguyen T-AD, Kim K-R, Kim MS et al. (2010) Thermophilic hydrogen fermentation from Korean rice straw by Thermotoga neapolitana. Int J Hydrogen Energy 35:13392-13398.

Nissila ME, Li YC, Wu SY et al. (2012) Dark Fermentative Hydrogen Production from Neutralized Acid Hydrolysates of Conifer Pulp. Appl Biochem Biotechnol 168:2160-2169.

Ogeda TL, Petri DFS (2010) Hidrólise Enzimática de Biomassa. Química Nova 36:1549-1558.

Ozkan L, Erguder TH, Demirer GN (2011) Effects of pretreatment methods on solubilization of beet-pulp and biohydrogen production yield. Int J Hydrogen Energy 36:382389 .

Palmqvist E, Hahn-Hagerdal B (2000) Fermentation of lignocellulosic hydrolysates. II: inhibitors and mechanisms of inhibition. Bioresour Technol 74:25-33.

Pan CM, Ma HC, Fan YT et al. (2011) Bioaugmented cellulosic hydrogen production from cornstalk by integrating dilute acid-enzyme hydrolysis and dark fermentation. Int J Hydrogen Energy 36:4852-4862.

Panagiotopoulos IA, Bakker RR, de Vrije T et al. (2010) Pretreatment of sweet sorghum bagasse for hydrogen production by Caldicellulosiruptor saccharolyticus. Int J Hydrogen Energy 35:7738-7747.

Pattra S, Sangyoka S, Boonmee M et al. (2008) Bio-hydrogen production from the fermentation of sugarcane bagasse hydrolysate by Clostridium butyricum. Int J Hydrogen Energy 33:5256-5265.

Pawar SS, Nkemka VN, Zeidan AA et al. (2013) Biohydrogen production from wheat straw hydrolysate using Caldicellulosiruptor saccharolyticus followed by biogas production in a two-step uncoupled process. Int J Hydrogen Energy 38:9121-9130.

Quemeneur M, Bittel M, Trably E et al. (2012a) Effect of enzyme addition on fermentative hydrogen production from wheat straw. Int J Hydrogen Energy 37:10639-10647.

Quemeneur M, Hamelin J, Barakat A et al. (2012b) Inhibition of fermentative hydrogen production by lignocellulosederived compounds in mixed cultures. Int J Hydrogen Energy 37:3150-3159.

Rafrafi Y, Trably E, Hamelin J, et al. (2013) Sub-dominant bacteria as keystone species in microbial communities producing bio-hydrogen. Int J Hydrogen Energy 38:4881-5180.
Raj SM, Talluri S, Christopher LP (2012) Thermophilic Hydrogen Production from Renewable Resources: Current Status and Future Perspectives. Bioenergy Res 5:515-531.

Ren N, Wang A, Gao L et al. (2008) Bioaugmented hydrogen production from carboxymethyl cellulose and partially delignified corn stalks using isolated cultures. Int J Hydrogen Energy 33:5250-5255.

Ren N, Wang A, Cao GL et al. (2009) Bioconversion of lignocellulosic biomass to hydrogen: Potential and challenges. Biotechnol Adv 27:1051-1060.

Ren NQ, Cao GL, Guo WQ et al. (2010) Biological hydrogen production from corn stover by moderately thermophile Thermoanaerobacterium thermosaccharolyticum W16. Int J Hydrogen Energy 35:2708-2712.

Rezende CA, de Lima MA, Maziero P et al. (2011) Chemical and morphological characterization of sugarcane bagasse submitted to a delignification process for enhanced enzymatic digestibility. Biotechnol Biofuels 4:1-18.

Sagnak R, Kargi F, Kapdan IK (2011) Bio-hydrogen production from acid hydrolyzed waste ground wheat by dark fermentation. Int J Hydrogen Energy 36:12803-12809.

Saratale G, Chen SD, Lo YC et al. (2008) Outlook of biohydrogen production from lignocellulosic feedstock using dark fermentation - a review. J Sci Ind Res 67:962-979.

Saripan AF, Reungsang A (2013) Biohydrogen production by Thermoanaerobacterium thermosaccharolyticum KKUED1: Culture conditions optimization using xylan as the substrate. Int J Hydrogen Energy 38:6167-6173.

Sarks C, Jin M, SatoTK et al. (2014) Studying the rapid bioconversion of lignocellulosic sugars into ethanol using high cell density fermentations with cell recycle. Biotechnol Biofuels 15:73-80

Seol E, Kim S, Raj SM et al. (2008) Comparison of hydrogen-production capability of four different Enterobacteriaceae strains under growing and non-growing conditions. Int J Hydrogen Energy 33:5169-5175.

Shaw AJ, Jenney FE Jr, Adams MWW et al. (2008) End-product pathways in the xylose fermenting bacterium Thermoanaerobacterium saccharolyticum. Enzyme Microb Technol 42:453-458.

Show KY, Lee DJ, Tay JH et al. (2012) Biohydrogen production: Current perspectives and the way forward. Int J Hydrogen Energy 37:15616-15631.

Song ZX, Wang ZY, Wu LY et al. (2012) Effect of microwave irradiation pretreatment of cow dung compost on bio-hydrogen process from corn stalk by dark fermentation. Int J Hydrogen Energy 37:6554-6561.

Sun Y, Cheng JY (2002) Hydrolysis of lignocellulosic materials for ethanol production: a review. Bioresour Technol 83:111.

Tai J, Adav SS, Su A et al. (2010) Biological hydrogen production from phenol-containing wastewater using Clostridium butyricum. Int J Hydrogen Energy 35:13345-13349.

Talluri S, Raj SM, Christopher LP (2013) Consolidated bioprocessing of untreated switchgrass to hydrogen by the extreme thermophile Caldicellulosiruptor saccharolyticus DSM 8903. Bioresour Technol 139:272-279.

Valdez-Vazquez I, Poggi-Varaldo HM (2009) Hydrogen production by fermentative consortia. Renew Sust Energ Rev 13:1000-1013. 
Vargas Betancur GJ, Pereira Jr N (2010) Sugar cane bagasse as feedstock for second generation ethanol production. Part I: Diluted acid pretreatment optimization. Elect J Biotechnol 13.

Veeravalli SS, Chaganti SR, Lalman JA et al. (2013) Effect of furans and linoleic acid on hydrogen production. Int J Hydrogen Energy 38:12283-12293.

Wang A, Ren N, Shi Y et al. (2008) Bioaugmented hydrogen production from microcrystalline cellulose using co-culture Clostridium acetobutylicum X-9 and Ethanoligenens harbinense B-49. Int J Hydrogen Energy 33:912-917.

Wang J, Wan W (2009) Factors influencing fermentative hydrogen production: A review. Int J Hydrogen Energy 34:799811.

Wu J, Upreti S, Mozaffari FE (2013) Ozone pretreatment of wheat straw for enhanced biohydrogen production. Int J Hydrogen Energy 38:10270-10276.

Xing Y, Fan SQ, Zhang JN (2011) Enhanced bio-hydrogen production from corn stalk by anaerobic fermentation using response surface methodology. Int $\mathrm{J}$ Hydrogen Energy 36:12770-12779.
Xu JF, Ren N, Su DX et al. (2010) Bio-hydrogen production from acetic acid steam-exploded corn straws by simultaneous saccharification and fermentation with Ethanoligenens harbinense B49. Int J Hydrogen Energy 34:381-386.

Yang Z, Guo R, Xu X et al. (2011) Fermentative hydrogen production from lipid-extracted microalgal biomass residues. Appl Energy 88:3468-3472.

Zhang M-L, Fan Y-T, Xing Y et al. (2007) Enhanced biohydrogen production from cornstalk wastes with acidification pretreatment by mixed anaerobic cultures. Biomass Bioenergy 31:250-254.

Zhao L, Cao G-L, Wang A-J et al. (2013) Simultaneous saccharification and fermentation of fungal pretreated cornstalk for hydrogen production using Thermoanaerobacterium thermosaccharolyticum W16. Bioresour Technol 145:103107.

Zhao L, Cao G-L, Wang A-J et al. (2013) Enzymatic saccharification of cornstalk by onsite cellulases produced by Trichoderma viride for enhanced biohydrogen production. GCB Bioenergy 5:591-598.

Associate Editor: Lara Durães Sette

All the content of the journal, except where otherwise noted, is licensed under a Creative Commons License CC BY-NC. 